\title{
ON the Beautiful and THe UgLY
}

\author{
Herman Parret
}

\begin{abstract}
Classical aesthetics sees the experience of the beautiful as an anthropological necessity. But, in fact, the beautiful is rather the central category designating classical art, and one can question the relevance of this category considering contemporary art. The reference term most frequently used for contemporary art is interesting: works of art solicit the interests of my faculties (the cognitiveintellectual, the pragmatic community-oriented moral, the affective aesthetic faculties). It is interesting to notice that the categories of the beautiful and the ugly have an axiological-moral value. It looks as if the qualities of contemporary art works are judged according to the intensity of the impact on the interests of our faculties. It reveals important, in this respect, to distinguish the ugly from the sublime and the monstrous. Kant's Third Critique is of some importance in defining these categories.
\end{abstract}

KEYWORDS: Formlessness. The abject. Formalism. Functionalism. The ugly and evil. The axiological value of the beautiful and the ugly. The sublime. The monstrous. The colossal. Nostalgia for beauty.

1

The question 'what is beauty' has had since Plato a prominent place in Western philosophy. Yet aesthetics as a scientific, philosophical

${ }^{1}$ Herman Parret studied at the University of Leuven where he obtained a licentiate in Romance Philology and a Ph.D. in Philosophy. He studied at the Ecole des Hautes Etudes en Sciences Sociales in Paris, at M.I.T., Cambridge, Mass., at the University of California at Berkeley and at Stanford University. He was Director of Research at the Belgian National Fund for Scientific Research and at the same time Professor at the University of Antwerp and Full Professor at the University of Leuven where he taught philosophy of language and philosophical aesthetics at the Institute of Philosophy and at the Department of Art Sciences. He is also affiliated at the Università degli Studi di Siena. He has been Invited Professor at the Universities of Campinas and São Paulo (Brasil), Tel Aviv, the University of California at San Diego, and he delivered innumerable lectures and papers at various foreign universities. He has also been professor at the Institut Universitaire de France and associated director at the Ecole des Hautes Etudes en Sciences Sociales. He published more than 230 articles in French, in English and in Dutch in the fields of the philosophy of language, semiotics and aesthetics. 
discipline having beauty as its object begins in the first half of the eighteenth century with Alexander Baumgarten who invents the concept 'aesthetica' and establishes its domain of research. An important ambition of this new philosophical discipline consists in the construction of so-called 'aesthetic categories', 'aesthetic values' or 'aesthetic predicates'. Throughout the entire history of aesthetics the beautiful and the sublime have served as the central aesthetic categories. Thus the question was: under which condition can the predicate 'beautiful' or 'sublime' be ascribed to an object, a situation or an event? Furthermore, a problem was raised, which I will hereby particularly attend to, namely whether the $u g l y$ can be considered as an aesthetic category. Is there an aesthetic experience of the ugly? Or even: what is the relation between the ugly and the beautiful?

One can indeed ask the pertinent question regarding the significance of such an abstract discussion about 'aesthetic values'. One can above all have doubts about the relevance of aesthetic categories such as the beautiful and the sublime in relation to contemporary art or to the contemporary experience of art. Has the ugly maybe become the only valid aesthetic predicate in the guise of formlessness and the abject? However, both in the production and the theory of art, the decline of beauty is a certainty. Maybe, as Adorno has already argued, beauty - and then the "new beauty" - can only be approached by taking distance from the beautiful. This withdrawing beauty still fascinates: it haunts us constantly, it does not let go of us. After the nineteenth century, the ascension of the beautiful and the sublime follows Hegel, who is largely responsible for the idea of the 'decline of beauty'. But the destruction of beauty can be even more radical. There is a tendency nowadays to link the experience of the beautiful to a conservative political position, to the bourgeois culture, to a regressive social taste. The very idea of modernity would then be essentially linked to the condemnation of the beautiful as aesthetic value and norm. That is why it is maybe better to no longer use the term 'beautiful' altogether and that happens often nowadays. The term 'beautiful' is being used less and less when visiting museums or listening to a concert, while the predicate interesting prevails upon beautiful. The times are long gone when Baudelaire proffered beauty as the only 'right' label that could determine his love for art.

This retreat is echoed in Paul Valéry's jest: "Beauty is a kind of death". Antonin Artaud, together with the artists Soutine and Bacon, join forces and turn 'beauty' into 'cruelty' (cruauté) and sadomasochism. The most contemporary art 
certainly questions the existence, the significance and the value of the beautiful in favour of the new, the intense, the uncanny, as Deleuze writes somewhere. Our time concentrates on all sorts of mutations, our mentality has become time-sensitive and all this disputes the beautiful since beauty is unchanging and stable. Beauty is calm, serene, harmonious and brings about only contemplation. From Breton to Lyotard, precisely this becomes a subject of a fundamental criticism. "Beauty will be convulsive or not at all", writes Breton. The introduction of the unconscious welcomes us into the age of the Differend (le differend, Lyotard), including a revaluation of the instant and of instability, disorder and imperfection. Valéry concludes that aesthetics is no longer a science of the beautiful but it became a science of sensations, a science of a convulsive subjectivity whose sensitivity functions chaotically and is context-dependent. Indeed, contemporary art has subverted the classic aesthetics of the beautiful. However, this cannot result in an a priori, global and desperate renunciation of the idea of beauty. This problematisation described above raises new questions that I shall approach in the following. Is there a formless beauty? Does formlessness lead to ugliness? Can we aesthetically experience ugliness?

2

Firstly, I shall determine what beauty cannot be. A particularly fashionable and seductive yet suspicious conception of the beautiful is found in the sociology of taste, like the way Bourdieu elaborates it in his book Distinction: A Social Critique of the Judgment of Taste (1979). In this epochmaking study, Bourdieu is interested in the variety of things that are found beautiful. He explains the experience of beauty from the perspective of more global social phenomena. For instance, the greater the knowledge of art and its enjoyment, the higher the education and the social status. Bourdieu does not hesitate to return to his argument that aesthetic 'taste' is nothing but a means for the social elite to display its superiority. He concludes that beauty is a political means that structures social relationships. Art enthusiasts in our society are thereby snobs manipulating a cruel thing in order to exclude other people. But, against Bourdieu, the question can be asked whether everyone who is highly educated is also open to art. Are not things more complex than that? Furthermore, Bourdieu's sociology deals only with general models of reaction and not at all with individual experiences. The social distribution 
is not essential to the insight into the love for art but rather, I think, the psychological embedment of the feeling of beauty.

Another exceptionally strong paradigm for the explanation of the 'subjective' feeling for beauty is equally reductionist. It is the biological evolutionary perspective. Evolutionary biologists argue that the love of beauty is necessary for survival. Attachment to beauty benefits human self-preservation and thereby it became a basic human skill. Think of the Venus of Urbino, of all the representations of Venus from the Renaissance, of all female figures that Titian painted. The allure of all these female bodies would be related to procreative mechanisms, just like the muscular athletic bodies of the representations of Apollo and Adonis attest to the virility of the fighter or the hunter, thus to the power of survival. This does not seem to be the case in a lot of contemporary art, like Bacon or Lucian Freud for instance, where the man-female contrast is settled so to speak.

What is beauty then? Are there possible theories as alternatives to sociologism and biologism? In the following I shall discuss a few other theories of beauty: object- and subject-oriented theories on the one hand and, on the other hand, perspectives on beauty where sensibility and materiality play a central part as distinct from perspectives that appeal to the supersensible.

Object-oriented theories of beauty attempt to conceptually grasp the 'secret' characteristics of the beautiful. These are the theories of proportion, the perfect composition, the sinuous lines and the form- and function dialectics. They pretend to be objective. The doctrine of proportion, harmony, perfect symmetry, geometrical purity, of Pythagoras (the right angle, the bodily proportions) about Palladio (a column must be nine times higher than its width) up to Marilyn Monroe (the ideal breast circumference) are all doctrines that reduce the experience of beauty to a concept, to an insight in a relation according to a given ratio, to the insight into the structure of the cosmos in its entire ideality. Such aesthetics are called formal but there are many kinds of 'formalisms' that are, for that matter, well matched. Generally, formalisms consider the essence of beauty as a characteristic of a holistic nature: beauty is the rule of the whole, of the combination of separate elements, of interrelations and juxtapositions within the object. The particular elements must go hand in hand in a 'composition' without losing their identity through their relationship to a totality. 
Functionalist theories of beauty are equally object-oriented and objectifying. A functionalist aesthetics teaches us that visual pleasure is found in the objects' adequate usability. According to functionalism, the integrity of an object consists in the perfect combination of form and function: the more the function determines the form, the more beautiful the object is. Such a theory of beauty pleads for the removal of all redundancies, for the purely decorative, for the elimination of everything that can seem frivolous, gracious and elegant. This functionalist perspective is difficult to sustain. Duchamp's theory of the readymade argues that for the object to be seen as object of art it has to lose its function. A functionalist theory of art is also anti-intuitive: what about the beauty of colours? What is the function of colours in their combinations and abstraction?

On the other hand, there are subject-oriented perspectives that highlight the subjective reaction of the one experiencing, cultivating and valuing the beautiful. The experience of beauty concerns the state of someone's mind ${ }^{2}$ (Gemüth). This subject-oriented aesthetics can be considered the 'Copernican revolution' in the history of theories about beauty. It was Immanuel Kant and his Critique of Judgment (1790) that introduced this idea. The aesthetic experience, the intensity of the gratification, even the feeling of bliss (Kant speaks of Woblgefallen, a state of being well-disposed) in the contact with natural beauty or with the beauty of an artwork become the theme of philosophical aesthetics. Kant is clear regarding this: an aesthetic experience is impossible without a feeling of gratification, without a special 'mood' and this 'mood' is intimate, personal and subjective. Moreover, no moral or political engagement, no interests or any other desires may disturb this 'mood'. The reception of the latter condition, the disinterestedness, has been especially problematic. Nietzsche, for instance, considered it purely hypocritical and James Joyce, in his A Portrait of the Artist as a Young Man, makes Stephen Dedalus reproach his friend Lynch: "I told you that one day I wrote my name in pencil on the backside of Venus of Praxiteles in the Museum. Was that not desire?" Kant, by contrast, will insist that the feeling of beauty has nothing to do with desire.

\footnotetext{
2 Translator's note: the German term Gemüth is hereby translated as 'mind' just to follow the existing English translations of Kant's Third Critique. However, the meaning of this German word does not refer to concepts, knowledge or any determination about an object (as the word 'mind' suggests) but rather to the mind's disposition, to the feeling of the mind's faculties caught in a reflexive stance,
} without an actual content. 
According to Kant, beauty frees us from the dungeon of desire while desire and beauty are of different orders.

Being touched (Rübrung) is thus central in this subject-oriented approach: beauty must move us to tears, it is in and through beauty that we discover our deepest 'self' or, as Plotinus thought, "the divine in us". Beauty leads to an 'inner fusion', a fusion of what we actually are and what we should have been. No wonder that the romantics, since Schiller, have considered the feeling of beauty as the longing for subjective perfection: beauty leads to an 'aesthetic paradise' which is actually the postulate of aestheticism: longing for beauty fills our entire existence.

Within this subject-oriented paradigm another equally important polarity can be discovered, namely the one between theories of beauty that rest entirely on the subject's sensibility and theories of beauty that appeal to a capacity that allows us to 'get in touch with' the supersensible. The fact that beauty is 'the divine in us', as Plotinus argues, or that it leads to an 'aesthetic paradise', points out that the kind of mind which experiences beauty is 'directed' towards the supersensible that Kant stipulated as the idea that 'transcends' all sensitivities and even some sensitivities that are transformed by the imagination.

\section{3}

In the following I take up the Kantian subject-oriented position and argue that beanty is the correlate of the mind determined by an intense, sensuous impression that brings pleasure and aims at a transcendental idea. This determination excludes some alternatives like, among others, all objectivist theories both formalistic and functionalistic but also theories of beauty where the dimension of pleasure is considered as exclusively sensuous.

Now I would like to approach a somehow more difficult 'category': the $u g l y$. Is the ugly opposed to beauty? Does it make sense to speak about the beauty of the ugly or about the beautiful representation of the ugly? Is ugliness necessary in order to speak about the beautiful? In chapter $\mathrm{V}$ of his History of Beauty (2004) Umberto Eco discusses the so-called 'beauty of monsters'. He returns to this subject in his more recent On Ugliness (2007) where he puts forward, next to an extended iconography of ugliness, a 
coherent philosophical theory that passes through the entire art history and philosophy of art until the present. Eco argues, among other things, that in many cultures the depictions of disfigured, horrifying beings (Priapos, the Minotaur, the Cyclopes) are positively valued. With Aristotle, he points out that art can also always depict ugly beings in a beautiful way and that it is precisely the beauty of the confrontation that makes the ugly acceptable. He writes: "The Ugliness that repels us in nature exists, but it becomes acceptable and even pleasurable in the art that expresses and shows 'beautifully' the ugliness of Ugliness" (ECO, 2004, 133) The representation of the ugly can be extended: scenes of torture, agony and sorrow next to the monstrous and to the physical disfiguration. Still, the degree of acceptance of 'beautiful' representations of such scenes seems to seriously differ: from the depiction of Satan or of a satyr to the photograph of a concentration camp or a video of the collapsing Twin Towers, it becomes more and more difficult to find these representations 'beautiful'. 9/ 11 was, according to Karlheinz Stockhausen, the most sublime spectacle ever but he insulted everyone with this statement.

Philosophers and especially theologians (in Antiquity and in the scholastic Middle Ages) conceived a theoretical explanation for the presence of the ugly in art, namely that the created universe is a whole that has to be valued in its totality. The Creation is seen as a whole where shadows make the light shine in a more beautiful manner and where the ugly belongs to a general order and it can accordingly look beautiful. Order may be beautiful in its totality but this order makes place for the monstrous that contributes to the balance within this order. According to this philosophical argumentation the universe's beauty increases due to the diversities. The ugly, the monstrous will keep on charming and fascinating. When moving from the representation of the $u g l y$ (the 'beauty of the devil') to the representation of evil, a positive evaluation becomes more difficult but not completely impossible. The 'aesthetics of evil' prevails at the end of the nineteenth century in the decadentism of, for instance, Oscar Wild or in Arthur Rimbaud's radical "derangement of all the senses".

The aesthetic appreciation of ugliness remains controversial. It is all the more remarkable that very little philosophic research has been done on the aesthetic phenomena of ugliness. An exception is Karl Rosenkranz's The Aesthetics of the Ugly (or the despicable), published in 1853 (four years before Baudelaire's The Flowers of Evi). In this work Rosenkranz puts 
forward a dialectical, Hegelian approach to the ugly, completely in line with medieval holistic theology: no beauty without ugliness, no ugliness without beauty. Paradoxically, Rosenkranz was Kant's successor at the University of Köningsberg and still he breaks down the Kantian aesthetics at its foundation. Rosenkranz comes up with a phenomenology of ugliness: he brings together in a dialectical fashion the beauty of proportions and of general formalness and the formlessness or the absence of formalness. Surely this is orthodox Hegelianism: by introducing the aesthetic experience in temporality, in historicity, in the dialectical history of humanity, the dualism of the beautiful and the ugly must come to an end. Rosenkranz explicitly relates ugliness, evil and the diabolical. In a classic Hegelian gesture, the negative is sublated into the ugly. This is not my position but still, the aesthetics of Rosenkranz was well received. Indeed, this unique Aesthetic of the Ugly has a double significance. On the one hand it concerns an exceptionally systematic and strong theory where ugliness is related to the play of formalness and formlessness and, on the other hand, the ugly is set against a uniquely detailed phenomenology and is (partly) ratified with adjacent aesthetic categories like the vulgar, the base, the repulsive, the caricatural, the ghostly and so on. Rosenkranz does not hesitate at all: there surely is an aesthetic experience of the ugly. That this is so for Rosenkranz is coherent within a Hegelian aesthetics yet within the Kantian paradigm, to which I subscribe, the question remains whether a pure aesthetic experience of the ugly is possible. In the following I shall shortly examine the Kantian suspicions regarding this issue in order to subsequently look at the relevance of such a discussion for the comprehension of contemporary art production.

\section{4}

Each aesthetic category is not merely descriptive, it also includes an axiological value: it values either 'favourably' and positively or 'unfavourably' or negatively. Some categories oscillate between the two values. Take 'nice', that is generally 'fairly positive' but often very quickly disappears and loses its value. The axiological values of these categories are often shifting and it is most of all difficult to weigh up their pros and cons. And still, it seems that the ugly has for everyone an unfavourable and negative value without any succession towards the positive. To say that an object is ugly does not just mean to affirm how an object is but what is its value. To predicate ugliness to 
an object is an aesthetic sentence. To say that an artwork is ugly is to argue that it failed due to some technical incapability or imperfection. Ugliness in nature is deemed as a mistake in the Creation. Consequently, an individual animal that is monstrous is considered as an exception within the species, as a failure of nature.

My first conclusion is: it is impossible to make abstraction of the axiological character of the ugly. Ugliness is not a descriptive but an evaluative category and has a necessary affective meaning. In German bässlich means both 'hateful' and 'ugly' and also the etymology of the French laid shows that it comes from the German word leiden, to suffer. Already this etymology points out the great affective weight of the term French term laid. In Dutch too, lelijk, even in the most quotidian meaning, has an inauspicious connotation. Ugliness is formless and lacks internal structure, balance and symmetry. The ugly is not complete, it deviates from the norm. This is how one grasps the meaning of ugliness. The predicate 'ugly' is also difficult to grasp from a logic point of view. The ugly is, logically, not the opposite of 'beautiful' and that is why the ugly and the beautiful are not contradictory but rather logically antipodal: they exclude each other but they do leave the door open to neutral intermediary terms: 'notbeautiful' and 'not-ugly' do not coincide with 'ugly' or 'beautiful'.

Another complex problem concerns the possibility of an aesthetic experience of the ugly. Kant does not provide an ultimate solution to this problem. The 'Analytic of the sublime' could provide a possible answer since in the experience of the sublime the imagination is hurt, and yet still there is pleasure. Pain mediates the pleasure that one experiences in the sublime. The experience of the sublime brings the mind into a state of tension and relaxation. What is significant is that even in this situation the mind is still able to have an aesthetic experience. Still, there is a border in the 'rape' of the imagination. One type of transgression is inadmissible and if this border is trespassed then the domain of the aesthetic is left behind. Here one has to take up the technical aspect of the Kantian argumentation. Kant distinguishes in the paragraph 26 of the Critique of Judgment between the monstrous (Ungehener) and the colossal (kolossalisch). The colossal, the monumental, the gigantic, the 'just too big' are still within the aesthetics of the sublime. Think of the immense dimensions of Christo's works that our imagination can hardly grasp. The colossal offers indeed a typical strategy for the sublime in contemporary arts. But opposed to that and on the other side of the border there is the monstrous. An object is 
'monstrous' when, due to its formlessness, it completely paralyzes the mind. While the colossal incites a feeling of the sublime, the monstrous paralyzes and impairs the mind and this is precisely what the ugly does. Maybe there are degrees of ugliness but the 'ultimate ugliness', the monstrous eliminates even the possibility of an aesthetic experience. Thus, in the paragraph 26 of the Critique of Judgment one can find a criterion to distinguish the sublime from the ugly. The same distinction appears in Kant's Anthropology. Kant distinguishes between two sorts of 'magnitudes': the magnitudo reverenda and the magnitudo monstruosa. The magnitudo reverenda is a magnitude that compels respect like, for instance, in the passion of astonishment. This is exactly the kind of 'magnitude' whose effect is the sublime. The opposite of this is the magnitudo monstruosa - this is a 'magnitude' that brings about deterrence (Abschreckung), dread and a strong anxiety. Kant calls this, in his Critique of Judgment, the monstrous (Ungeheuer) which destroys imagination and whose violence is so intense that the pain is unbearable. Here, there is no mediation of pain and pleasure like in the experience of the sublime. This is the domain of the 'ultimate ugliness', which is actually unimaginable and whose affective effect is disgust (Ekel) or loatbing.

But Kant is not always just as clear in the delineation of the sublime and the ugly. Yet an attentive reading of the Critique of Judgment and of the Anthropology allows me to formulate a double conclusion. First of all, as it has been shown hereby, the ugly cannot be conceived as contradictory to the beautiful but rather it has to be grasped in its relation to the sublime: the ugly is 'on the other side' of the sublime, beyond the sublime, as radically unconceivable and ungraspable by our representational faculties and our imagination. Consequently, there is no place for the very concept of an aesthetic experience of the ugly, not in Kant and at the same time not in classic aesthetics. An aesthetic experience of the ugly is impossible due to the complete deferment and paralysis of human faculties. Ugliness is outrageous: during such an experience our mind undergoes a feeling of disgust and such a disgust allows no aesthetic relation but merely a moral attitude. After all, this is how I began this analysis of the ugly: in the domain of the ugly the spontaneous reaction is axiological. We are forced to take a moral stance in the presence of the ugly and thereby another interest of reason than the pure aesthetic interest motivates us. 
Even though in the foregoing I have argued that a classic aesthetic theory of the ugly is not possible, this does not imply that an 'experience of ugliness' is impossible. Furthermore, the contemporary visual arts elicit frequently such an experience. This just means that the beautiful is no longer a pertinent aesthetic category to be employed in characterizing the contemporary object of art and that more pertinent predicates have to be sought. For that purpose one can appeal to the 'subversive' Kantian category of the monstrous (Ungehener) that Kant himself placed outside the aesthetic domain. A few contemporary philosophers can also help us and argue that the monstrous, in its unconceivable character, is actually the thingness: the 'Thing' or 'the Thing as the unreachable object', as Lacan calls it, matter without form, the 'Differend', as Lyotard calls it. The bulk of contemporary visual arts would then show nothing but a (uncontrollable, unconscious) drive to reification. Contemporary arts are fascinated with the Thing which withdraws itself from any limitation and formation.

The entire history of art has been a conflict between form and matter. This has been preeminently the case with the great modernists, like Picasso, Matisse, Kandinsky and Mondriaan. The antagonists of this conflict came to the fore in the sixties of the last century: one sees an extreme formalism (or conceptualism) over against an extreme matierism. The attraction of the naked and brute material thingness catches the attention of many significant guiding figures of contemporary arts, from Beuys to Kienholz to McCarthy and Kelly. Yves-Alain Bois and Rosalind Kraus offered an outstanding analysis of this dynamic in their book Formless (1997). Three phases can be distinguished in the battle against form as it is embodied in the contemporary arts: the antiform, the formlessness and the abject. Robert Morris conceived in the sixties the notion of anti-form as a reaction against classical art which held in esteem the solidity and the nobility of materiality. Morris pleaded for horizontality and the banal materials (felt, disposable and synthetic materials); he argued for flaccidity, slime, fluidity and the fold. The formlessness brings us even closer to the ground and the accidental while Bataille's notion of the 'scatological matter' illustrates this way towards matter. According to Bois and Kraus, the abject is reached when also evoking entropy and pulsation. Entropy concerns the general transience of matter, the pulsation the rhythmic temporality as outburst of bodiliness, the pulsation of desire ('the pulse of life'). According to Julia Kristeva the 
'abject' is the junction between subject and object, being no-longer-subject and the not-yet-object, the undifferentiated and unutterable membrane which provokes a physical disgust. Such a description fits in harmoniously in with the Kantian Ungeheuer. Art history has known many periods that aimed at 'matierism'. In the twentieth century, for instance, think of the informal art or the arte povera. From the sixties, the modernist paradigm's change of direction to the contemporary arts has surely confirmed the glory of matierism. I just mention Serrano and McCarthy where matierism reaches its climax and also its ugliness. The radical matierism is, of course, the universe of the $u g l y$, the mutilated flesh, the decay, the melt down, the work of the heterogeneous 'Outside', of the unutterable that penetrates, the absolute triumph of matter over form, a far-reaching destabilization of our classifying categories and our artistic concepts.

\section{6}

I conclude these reflections on the beautiful and the ugly with four statements.

As the first statement I argue that classical aesthetics, founded on the aesthetic categories of the beautiful, goes along with the idea that the experience of the beautiful is an anthropologic necessity. People need beauty and that is the case in all cultures. Everyone seems to have a feeling that our existence is impoverished without the experience of the beautiful. Of course, such an existential necessity brings about the nostalgia for beauty wherever beauty is absent. Maybe this first statement sounds too humanistic and idealistic and it might not even comply at all with the present needs of the contemporary man. Maybe today we need more provocation, authenticity, and excitation, and the contemplative attitude that the beautiful compels us to take is no longer attractive. This pure 'well-being' which is found when confronted with beauty seems to us even odd and egocentric. Collective enthusiasm seems to us even more moral than pure individual pleasure. Still, it seems to me, notwithstanding this rise of exciting and sometimes destructive vital forces, that the nostalgia for the beautiful and thereby the aesthetic attitude of contemplation and serenity is unavoidable and even ineradicable.

This brings us to the second statement. The beautiful as central aesthetic category undoubtedly designates the classical art, modernity included (hence 
up to 1960) and so beauty is definable within the classical art theory and aesthetics. Kant's 'Analytic of the beautiful' is here the model and the prototype. It offers the most adequate and universal deductive reconstruction of the state of mind that is 'moved' by beauty. Further I declare, and this is the third statement, that in the contemporary, so-called postmodern times beauty is dethroned. No "Abuse of Beauty" (Open Court Publishing, 2003), warns a still nostalgic Arthur Danto. It is absolutely clear that there are no longer any central and peripheral aesthetic categories. There is no longer a hierarchy between the manifold aesthetic predicates that culminate with the beautiful. The reference term most frequently used is equally the least specific, the most general: interesting. Artworks are or are not interesting. The semantics of the 'interesting' is the following: the 'interesting' is that which solicits my interest or, even better, the interests of my faculties. I think of the classic (Kantian) division of the interests of my faculties: the cognitive-intellectual faculty of knowledge, the pragmatic (community oriented) moral faculty, and the affective aesthetic faculty. Nowadays, when calling an art object 'interesting', one no longer declares anything about the specific faculties that are addressed. Calling something 'interesting' has cognitive, moral and aesthetic connotations. The dethronement of beauty concerns, amongst other things, the dissipation of the borders between the classical faculties of the subject.

And the fourth statement summarizes what has been previously said about the $u g l y$. Here too, Kant was the initiator. The ugly is not considered as opposed to the beautiful but as a continuation of the sublime: the extremelysublime is ugly. The ugly is thus not an aesthetic value or category but a postaesthetic one. And so Kant meets Lyotard. The 'value' of contemporary arts consists in infringing upon our imagination, raping it, and so that violent effect of the contemporary object of art brings about an immediate axiological-moral reflex regarding the identity, the authenticity, the integrity of being human. Hence, contemporary arts can no longer be judged and valued according to the quality of the aesthetic categories, beginning with the beautiful, but according to the intensity of the impact on the interests of our faculties. Let us calls this the new 'aesthetic excellence' or even, if it does not sound too paradoxical and ironic, the 'new beauty'. 
PARRET, Herman. On the Beautiful and the Ugly.Trans/Form/Ação, (Marília); v.34, p.2134, 2011, Edição Especial 2.

RÉSUMÉ: L’esthétique classique considère l'expérience du beau comme une nécessité anthropologique. Mais, il faut constater que le beau est surtout une catégorie qui désigne l'art classique, et on peut même poser la question si elle est pertinente pour l'art contemporain. Le terme de référence le plus employé pour évoquer l'art contemporain est celui de l'intéressant : les œuvres d'art sollicitent les intérêts de mes facultés (les facultés cognitivo-intellectuelle, pragmatique et moral orientée par l'insertion dans la communauté, et esthético-affective. Il est bien de noter que les catégories du beau et du laid ont une valeur axiologique et morale. Il semble que les qualités de l'art contemporain sont jugées à partir de l'intensité de l'impact sur les intérêts de nos facultés. Il se révèle important, de ce point de vue, de distinguer le laid d'une part et le sublime et le monstrueux d'autre part. La Troisième Critique de Kant est importante pour la définition de ces catégories.

MOTS-CLÉS: L'informe. L'abject. Formalisme. Fonctionnalisme. Le laid et le mal. La valeur axiologique du beau et du laid. Le sublime. Le monstrueux. Le colossal. La nostalgie pour la beauté. 